\title{
The Importance of New Anthropometric Measurements in Detecting Cardio Metabolic Risk and Insulin Resistance in Patients with Polycystic Ovary Syndrome: Single Center Experience
}

\author{
Gülsüm GÖNÜLALAN ${ }^{1} \oplus$, Fatih SAÇKAN² $\bullet$ \\ ${ }^{1}$ KTO Karatay University, School of Medicine, Medicana Konya Hospital, Department of Endocrinology and Metabolism, Konya, Turkey \\ ${ }^{2}$ Health Science University, Konya Research and Training Hospital, Department of Internal Medicine, Konya, Turkey \\ Cite this article as: Gönülalan G, Saçkan F. The Importance of New Anthropometric Measurements in Detecting Cardio Metabolic Risk and Insulin Resistance in Patients with \\ Polycystic Ovary Syndrome: Single Center Experience. Turk J Diab Obes 2021;1: 25-32.
}

\begin{abstract}
Aim: Abdominal obesity is frequently seen in Polycystic Ovary Syndrome (PCOS). The evaluation of abdominal obesity might be important according to metabolic and cardiovascular dysfunctions in patients with PCOS. We aimed to evaluate the new anthropometric measurements in patients with polycystic ovary syndrome (PCOS) and their relationship with cardiovascular risk and insulin resistance. Material and Methods: We included 62 patients with PCOS and 38 healthy individuals as control. The clinical examinations, serum hormone levels and ultrasonographic findings of overs were evaluated. Anthropometric Measurements, HOMA-IR values and Carotid intima-media thickness (CIMT) measurements were evaluated.

Results: The predictors of abdominal obesity as waist circumference, lipid accumulation product (LAP), body adiposity index (BAI), body roundness index (BRI), visceral adiposity index (VAI), abdominal volume index (AVI) and waist-height ratio (WHtR) were significantly higher in patient with PCOS $(\mathrm{p}<0.01)$. HOMA-IR and CIMT were also significantly higher in patients with PCOS compared with controls $(\mathrm{p}<0.01)$. We found significant correlations between anthropometric measurements and CIMT and insulin resistance. Anthropometric measurements were also valuable in prediction of PCOS.

Conclusion: Some of the measurements as BMI and waist/height ratio are used in evaluation of obesity. However, they had some limitations in prediction of obesity. We believe that recently used anthropometric measurements as waist circumference might be more useful predictors in evaluation of abdominal obesity and metabolic/cardiovascular risks in patients with PCOS.
\end{abstract}

Key Words: Polycystic ovary syndrome, Atherosclerosis, Anthropometry, Carotid intima-media thickness, Abdominal obesity

\section{Polikistik Over Sendromlu Hastalarda Yeni Antropometrik Ölçümlerin Kardiyometabolik Risk ve İnsülin Rezistansını Belirlemedeki Önemi}

ÖZ

Amaç: Polikistik Over Sendromunda (PKOS) abdominal obezite sıklıkla görülmektedir. Abdominal obezitenin değerlendirilmesi PKOS’lu hastalarda metabolik ve kardiyovasküler disfonksiyon açısından önemlidir. Bu çalışmada PKOS’lu hastalarda yeni antropometrik ölçümleri ve kardiyovasküler risk ve insülin rezistansı ile ilişkisini araştırmayı amaçladık.

Gereç ve Yöntemler: Çalışmaya 62 PKOS’lu hasta ve 38 sağlıklı kontrol dahil edildi. Hastaların klinik bulguları, serum hormon düzeyleri ve overlerin ultrasonik bulguları değerlendirildi. Antropometrik ölçümler, HOMA-IR düzeyleri ve karotis intima media kalınlıkları (KIMK) değerlendirildi.

Bulgular: Abdominal obezite belirteci olan bel çevresi, lipid akümülasyon skoru, vücut adipozite indeksi, beden şekli indeksi, visseral yağ indeksi, abdominal hacim indeksi ve bel-boy oranı PKOS’lu hastalarda anlamlı olarak yüksekti (p<0,01). HOMA-IR ve KIMK PKOS’lu hastalarda anlamlı olarak yüksek tespit edildi $(\mathrm{p}<0,01)$. Antropometrik ölçümler ile KIMK ve insülin rezistansı arasında istatistiksel olarak anlamlı korelasyon tespit edildi. Antropometrik ölçümler PKOS belirteci olarak da anlamlı bulundu.

ORCID: Gülsüm Gönülalan / 0000-0001-5465-944X, Fatih Saçkan / 0000-0003-0257-8917 
Sonuç: BKİve Bel/Boy oranı gibi antropometrikölçümler bazı kısıtlılıklara sahip olsa da obezite değerlendirmesinde kullanışlıdır. PKOS’lu hastalarda bel çevresi gibi yeni antropometrik ölçümler abdominal obezite ve metabolik/kardiyovasküler risklerin belirlenmesinde daha kullanışlıdır.

Anahtar Sözcükler: Polikistik over sendromu, Ateroskleroz, Antropometri, Karotis intima media kalınlı̆̆, Abdominal obezite

\section{INTRODUCTION}

Polycystic ovary syndrome (PCOS) with 5-10\% prevalence is the most frequently encountered endocrinopathy in women at reproductive age, and most commonly seen with hyperandrogenism and oligo-anovulation (1). PCOS occurs with menstrual disorders, infertility, androgen excess, insulin resistance, central obesity, dyslipidemia and increased type 2 diabetes mellitus frequency. In previous studies, it has been detected that subclinical inflammation increases in PCOS and insulin resistance (2).

Obesity is frequently seen in PCOS in comparison with healthy women. Obesity is detected in approximately $50 \%$ of patients with PCOS. Although PCOS is also seen in normal-weight women, the possibility of PCOS in obese women is higher. Obesity, especially abdominal obesity, triggers hirsutism and menstrual abnormalities and causes the clinical manifestation belonging to PCOS to occur. If a woman with PCOS is overweight or obese, the possibility of having reproductive and metabolic problems is higher (1).

It has been found that insulin resistance, metabolic syndrome and cardiovascular complications are closely related with visceral adipose tissue (3). Different devices, such as bioelectrical impedance, magnetic resonance imaging and DEXA, are used to show visceral adipose tissue distribution. Therefore, showing visceral adipose tissue is not an easy method (4).

The new anthropometric measurements as visceral adiposity index (VAI), lipid accumulation product (LAP), body adiposity index (BAI), abdominal volume index (AVI), body roundness index (BRI), and a body shape index (ABSI) were previously studied by several studies (5-9). These studies reported that some of these new anthropometric measurements were better to predict insulin resistance and cardiovascukar risk. According to these studies, the new measurements were better alternative for indexing obesity (5-9).

However there are frequently used measurements as waist circumference, body mass index (BMI), waist-hip ratio and waist-height ratio to display visceral adipose distribution, we purposed to measure new anthropometric measurements in PCOS in our study. BMI is insufficient to show the fat mass, fat distribution and cardiovascular risk. It is needed to found a better predictor for cardiovascular risk.
Therefore, we aimed to show the importance of new measurements to predict insulin resistance or cardiovascular risk in comparison with those frequently used anthropometric measurements.

\section{MATERIALS and METHODS}

Sixty-two patients with PCOS and 38 healthy individuals as control were included to our prospectively designed study. The patients were those who visited the outpatient clinic of Endocrinology and Metabolism Disorders with the symptoms of menstrual irregularity and/or hyperandrogenism between May and October 2019. 38 healthy individuals having similar age were included. The informed consent form of the study was signed by all patients. The clinical, biochemical and hormonal values and ultrasonographic findings of the control group were evaluated. They did not have any known chronic medication history. The patients with acute coronary syndrome, heart failure, stroke, pulmonary embolism, diabetes mellitus, renal failure, immunological disease history, ovarian tumors and congenital adrenal hyperplasia were excluded from the study.

This study has been approved by The Clinical Researches Ethical Committee of Necmettin Erbakan University (Number: 2019/1915). Declaration of Helsinki was followed in this study design and report.

\section{Diagnosis of PCOS}

2003 Rotterdam criteria were used in diagnosis of PCOS (10). Patients with PCOS have two of the following three criteria as oligo-anovulation, clinical and/or biochemical hyperandrogenism and polycystic ovaries.

\section{Anthropometric Measurements}

All measurements were done by the same investigator. Anthropometric Measurements included the weight, height, and waist and hips circumference. BMI was calculated by dividing body weight $(\mathrm{kg})$ by the square of height $\left(\mathrm{m}^{2}\right)$. Waist circumference was measured at the midpoint between iliac crests and the lowest rib while standing. Hip circumference was measured at the widest part of the hips (11). The average of these two values was taken as the waist-hip-ratio (WHR).

VAI was calculated in order to evaluate abdominal adiposity (12). In addition, LAP, BAI, AVI, BRI and ABSI were calculated using formulas (13-14). 
VAI $($ Males $)=[$ waist circumference $(\mathrm{cm}) / 36.58+$

$(1.88 \times \mathrm{BMI})] \times($ triglyceride/1.03 $) \times(1.31 / \mathrm{HDL}-\mathrm{K})$

VAI $($ Females $)=[$ waist circumference $(\mathrm{cm}) /(36.58+$

$(1.88 \times \mathrm{BM})] \times($ triglyceride $/ 0.81) \times(1.52 / \mathrm{HDL}-\mathrm{K})$

LAP $($ Males $)=($ waist circumference $(\mathrm{cm})-65) \mathrm{x}$

Triglyceride

LAP $($ Females $)=($ waist circumference $(\mathrm{cm})-58) \mathrm{x}$

Triglyceride

BAI (Males and Females) $=[$ Hip circumference $(\mathrm{cm}) /$ height $(\mathrm{m}) 1.5]-18$

$\mathrm{BRI}=364.2-365.5 \mathrm{x} \sqrt{ } 1-[($ Waist circumference/ $(2 \pi) 2) /$ (0.5x height) 2]

AVI $=\left[2 \mathrm{~cm}\right.$ (Waist circumference) ${ }^{2}+0.7 \mathrm{~cm}$ (WaistHip $\left.)^{2}\right] / 1,000$

ABSI=Waist circumference $\left(\mathrm{BKI}^{2 / 3} \mathrm{x}\right.$ Height $\left.{ }^{1 / 2}\right)$

\section{Carotid Artery Ultrasonography}

During the first examination Carotid intima-media thickness (CIMT) of the patients with PCOS and control group were measured as the distance between vein lumen echogenicity and media-adventitia echogenicity using LOGİQ P5 B-Mode Ultrasonographic device TM. Three measurements were performed from $1 \mathrm{~cm}$ proximal to both main carotid artery bifurcations and CIMT measurements were performed only from the posterior wall. The average CIMT was calculated from the average of measurements which were performed three times on both arteries.

\section{Laboratory Measurements}

After fasting overnight, venous blood samples were taken between 08-09 am. on the $3^{\text {rd }}-5^{\text {th }}$ day of the menstrual cycle. The levels of fasting blood glucose, fasting blood insulin and lipid profile were determined.

The cut-off point of triglyceride (TG) was accepted as $150 \mathrm{mg} / \mathrm{dL}$, the cut-off point of low density lipoprotein cholesterol (LDL-C) was accepted as $130 \mathrm{mg} / \mathrm{dL}$, the cut-off point of high density lipoprotein cholesterol (HDL-C) was accepted $50 \mathrm{mg} / \mathrm{dL}$ for females and as $40 \mathrm{mg} / \mathrm{dL}$ for males. Insulin resistance was calculated using homeostasis model assessment (HOMA-IR) formula [Fasting insulin $(\mu \mathrm{U} / \mathrm{mL})$ $\times$ Fasting glucose $(\mathrm{mg} / \mathrm{dl}) / 405)]$. HOMA-IR values $>2.7$ was accepted as insulin resistance according to Turkish metabolic syndrome guideline (15).

\section{Statistical Analysis}

SPSS 25.0 package program was used for the statistical analysis of the study (SPSS Inc, Chicago, Illinois, USA). The sample size was found by the calculation for the female population of Konya region with $95 \%$ confidence interval $(\alpha=0.05)$. Analytic and graphical studies were used for evaluating normal distribution. We evaluated the values by using skewness-kurtosis values and Kolmogorov-Smirnov tests in analytic evaluation and histogram, detrended Q-Q plot graphics for normal distribution. Mean \pm standard deviation was used in normally distributed numerical variables and median and range were used in non-normally distributed variables. Student $t$ test was used to compare the normally distributed variables between groups. The Mann-Whitney $U$ test was used to compare non-normally distributed variables in independent groups. Categorical variables of groups were compared by the chi-square $\left(\chi^{2}\right)$ test. Spearman correlation test was used to investigate the correlation between anthropometric parameters and CIMT and HOMA-IR. The diagnostic evaluation of the independent predictors as anthropometric parameters was calculated from ROC curve analysis and cut-off values were determined by the Youden's index. $p<0.05$ was accepted as statistically significant.

\section{RESULTS}

Sixty-two patients with PCOS whose ages ranged between 18 and 45 years old and 38 healthy individuals at the same range in the control group were included. The clinical, biochemical and hormonal values and ultrasonographic findings of the control group were detected in normal ranges. The blood pressure of the patients with PCOS and the control group was normal. The demographic, laboratory findings and the assessment of anthropometric measurements belonging to the individuals were given in Table 1 .

The average of ages of the patients with PCOS and the control group were similar $(\mathrm{p}=0.07)$. The mean $\mathrm{TG}$, total cholesterol and LDL-C level were found significantly increased in PCOS in comparison with the control group. Besides, the mean HDL-C levels between groups were similar.

Abdominal obesity indicators as waist circumference, LAP, BAI, BRI, AVI, VAI and WHtR of PCOS group were significantly increased $(\mathrm{p}<0.05)$.

We used the ROC curve analysis to found the best prediction value of variables in PCOS. The values of area under the curve (95\% confidence interval) according to anthropometric measurements were shown in Table 2. It has been determined that CIMT, VAI and LAP were best predictors in PCOS (Figure 1). Besides, the mean CIMT value of patients with PCOS was found significantly higher than the control group $(\mathrm{p}<0.01)$. There were correlations between CIMT and LAP, BAI, BRI, VAI and AVI (Table 3). In addition, there was a positive correlation between insulin resistance and waist circumference, LAP, VAI, AVI, BAI, BRI and BMI $(p<0.05)$ (Table 4). The values of area under the curve $(95 \%$ confidence interval) according to anthropometric measurements and insulin resistance in patients with PCOS were shown in Figure 2. 
Table 1: Demographic and metabolic characteristic of study participants.

\begin{tabular}{|c|c|c|c|}
\hline & Control $(n=38)$ & $\operatorname{PCOS}(n=62)$ & p value \\
\hline Age (years)* & $29(19-43)$ & $25(20-42)$ & 0.078 \\
\hline $\mathrm{WC}(\mathrm{cm})^{* *}$ & $83 \pm 11$ & $90 \pm 13$ & 0.004 \\
\hline $\operatorname{BMI}\left(\mathrm{kg} / \mathrm{m}^{2}\right)^{*}$ & $27.5(18.6-37.8)$ & $28.6(17.7-46.5)$ & 0.061 \\
\hline $\mathrm{HC}(\mathrm{cm})^{* *}$ & $99 \pm 9$ & $107 \pm 12$ & 0.001 \\
\hline CIMT $^{*}$ & $0.38(0.24-0.56)$ & $0.5(0.37-0.64)$ & $<0.001$ \\
\hline FPG $(\mathrm{mmol} / \mathrm{L})^{*}$ & $84(71-101)$ & $88(61-199)$ & 0.083 \\
\hline $\mathrm{TC}(\mathrm{mg} / \mathrm{dL})^{* *}$ & $176 \pm 29$ & $195 \pm 36$ & $0.006^{a}$ \\
\hline TG $(\mathrm{mg} / \mathrm{dL})^{*}$ & $68(41-356)$ & $127(30-493)$ & $<0.001^{\mathrm{a}}$ \\
\hline HDL-C $(\mathrm{mg} / \mathrm{dL})^{\star *}$ & $51 \pm 10$ & $47 \pm 11$ & 0.07 \\
\hline LDL-C (mg/dL) $)^{\star *}$ & $108 \pm 26$ & $121 \pm 30$ & $0.026^{a}$ \\
\hline Insulin* & $9.05(2.88-118)$ & $14.2(2.18-83.1)$ & $0.006^{\mathrm{a}}$ \\
\hline HOMA-IR ${ }^{*}$ & $1.94(0.5-27.68)$ & $3.02(0.4-25.65)$ & $0.004^{a}$ \\
\hline LAP $^{*}$ & $19.45(0.55-196.95)$ & 37.7 (7.59-238.39) & $<0.001^{a}$ \\
\hline BAI $^{*}$ & $30.82(18.04-41.65)$ & $32.35(24.63-46.28)$ & 0.023 \\
\hline BRI ${ }^{*}$ & $3.64(1.2-6.15)$ & $4.03(2.23-10.56)$ & $0.033^{a}$ \\
\hline VAI $^{*}$ & $1.03(0.52-13.99)$ & $2.22(0.4-13.83)$ & $<0.001^{\mathrm{a}}$ \\
\hline $\mathrm{AVI}^{*}$ & $13.72(6.56-22.92)$ & $15.63(10.33-32.26)$ & $0.014^{\mathrm{a}}$ \\
\hline ABSI $^{\star}$ & $0.08(0.06-0.09)$ & $0.07(0.06-0.11)$ & 0.306 \\
\hline WHtR $^{\star \star}$ & $0.51 \pm 0.07$ & $0.55 \pm 0.08$ & $0.007^{\mathrm{a}}$ \\
\hline $\mathrm{WHR}^{\star \star}$ & $0.83 \pm 0.07$ & $0.84 \pm 0.07$ & 0.382 \\
\hline
\end{tabular}

WC: Waist circumference, HC: Hip circumference, BMI: Body Mass Index, CIMT: Carotid intima-media thickness, FPG: Fasting blood glucose, TC: Total cholesterol, TG: Triglyceride, HDL-C: high density lipoprotein cholesterol, LDL-C: Low density lipoprotein cholesterol, LAP: lipid accumulation product, BAI: Body adiposity index, BRI: Body roundness index, VAI: Visceral adiposity index, AVI: Abdominal volume index, ABSI: A body shape index, WHR: Waist-hip ratio, WHtR: Waist-height ratio.

Data are presented as mean \pm standard deviation for normal distribution and as median (minimum-maximum) for non-normal distribution ${ }^{a} \mathrm{p}<0.05$ is statistically significant. ${ }^{\star}$ Compared with Mann-Whitney $\mathrm{U} \quad{ }^{* *}$ Compared with Student $\mathrm{t}$ test

Table 2: Receiver operation curve analyses of anthropometric indexes for PCOS

\begin{tabular}{lccccc}
\hline & AUC $(\mathbf{9 5 \%} \mathbf{C I})$ & P value & Cut-off value & Sensitivity (\%) & Specifity (\%) \\
\hline CIMT & $0.937(0.870-0.976)$ & $<0.001$ & $>0.44$ & 87.1 & 92.1 \\
\hline BMI $\left(\mathbf{k g} / \mathbf{m}^{2}\right)$ & $0.686(0.585-0.775)$ & 0.001 & $>30.02$ & 41.9 & 86.8 \\
\hline WC $(\mathbf{c m})$ & $0.641(0.539-0.735)$ & 0.012 & $>86$ & 56.5 & 65.8 \\
\hline HC $(\mathbf{c m})$ & $0.667(0.566-0.758)$ & 0.002 & $>102$ & 54.8 & 76.3 \\
\hline WHR & $0.545(0.442-0.645)$ & 0.449 & $>0.848$ & 56.5 & 60.5 \\
\hline WHtR & $0.627(0.525-0.722)$ & 0.026 & $>0.526$ & 56.5 & 65.8 \\
\hline LAP & $0.738(0.640-0.821)$ & $<0.001$ & $>31.5$ & 58.1 & 81.6 \\
\hline BAI & $0.635(0.533-0.729)$ & 0.019 & $>37.34$ & 25.8 & 97.4 \\
\hline BRI & $0.627(0.525-0.722)$ & 0.026 & $>3.87$ & 56.5 & 65.8 \\
\hline VAI & $0.743(0.646-0.825)$ & $<0.001$ & $>1.31$ & 74.2 & 68.4 \\
\hline AVI & $0.646(0.544-0.739)$ & 0.009 & $>15.02$ & 59.7 & 65.8 \\
\hline ABSI & $0.561(0.458-0.660)$ & 0.305 & $<0.072$ & 37.1 & 78.9 \\
\hline AUC & & &
\end{tabular}

AUC: Area under curve, CIMT: Carotid intima-media thickness, BMI: Body Mass Index, WC: Waist circumference, HC: Hip circumference, WHR: Waist-hip ratio, WHtR: Waist-height ratio, LAP: lipid accumulation product, BAI: Body adiposity index, BRI: Body roundness index, VAI: Visceral adiposity index, AVI: Abdominal volume index, ABSI: A body shape index. 


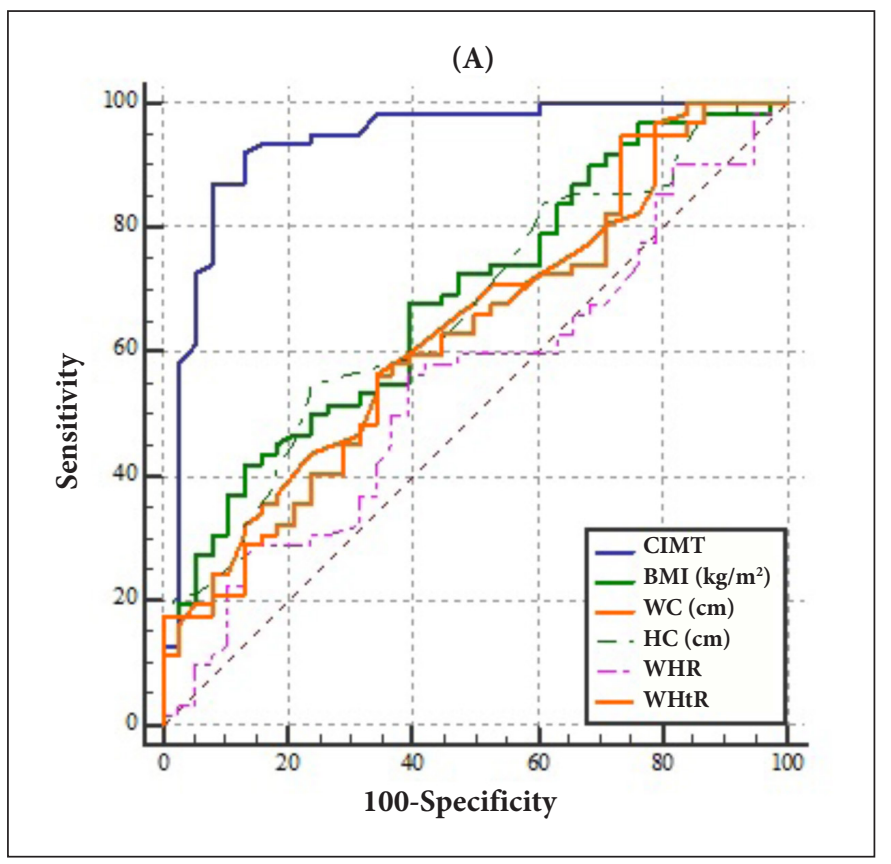

Figure 1. Area under curves of anthropometric parameters for PCOS.

Table 3: Correlation analyses results between CIMT and antrophometric measures

\begin{tabular}{lcc}
\hline & \multicolumn{2}{c}{ Carotis Intima Media Thickness } \\
\hline Parameters & Rho coefficients & P value \\
\hline BMI $\left(\mathbf{k g} / \mathbf{m}^{2}\right)$ & 0.394 & $<0.001^{\mathrm{a}}$ \\
\hline WC $(\mathbf{c m})$ & 0.344 & $<0.001^{\mathrm{a}}$ \\
\hline HC $(\mathrm{cm})$ & 0.364 & $<0.001^{\mathrm{a}}$ \\
\hline WHR & 0.159 & 0.113 \\
\hline WHtR & 0.310 & $0.002^{\mathrm{a}}$ \\
\hline LAP & 0.426 & $<0.001^{\mathrm{a}}$ \\
\hline BAI & 0.287 & $0.004^{\mathrm{a}}$ \\
\hline BRI & 0.310 & $0.002^{\mathrm{a}}$ \\
\hline VAI & 0.403 & $<0.001^{\mathrm{a}}$ \\
\hline AVI & 0.349 & $<0.001^{\mathrm{a}}$ \\
\hline ABSI & -0.082 & 0.416 \\
\hline B & BC: &
\end{tabular}

BMI: Body Mass Index, WC: Waist circumference, HC: Hip circumference, WHR: Waist-hip ratio, WHtR: Waist-height ratio, LAP: Lipid accumulation product, BAI: Body adiposity index, BRI: Body roundness index, VAI: Visceral adiposity index, AVI: Abdominal volume index, ABSI: A body shape index $\quad{ }^{a}<0.05$ is statistically significant.

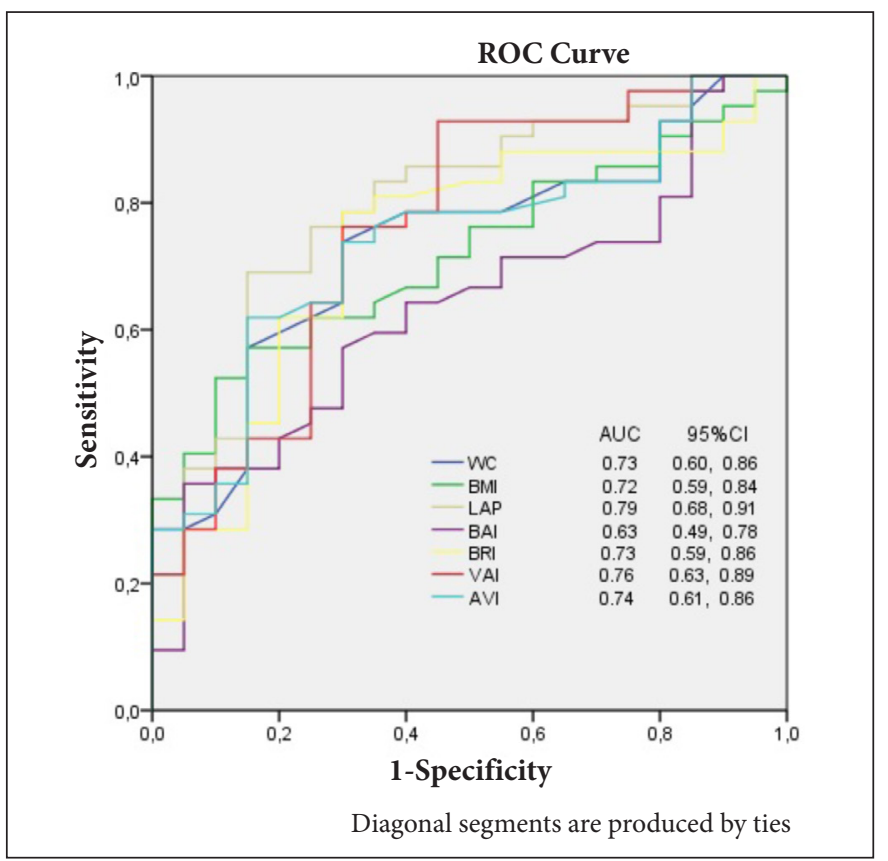

Figure 2. Area under curves of anthropometric parameters for Insulin resistance in patients with PCOS.

Table 4: Correlation analyses results between HOMA-IR and anthropometric measures

\begin{tabular}{lcc}
\hline & \multicolumn{2}{c}{ Homa-IR } \\
\hline Parameters & Rho coefficients & P value \\
\hline CIMT & 0.299 & $0.003^{\mathrm{a}}$ \\
\hline BMI $\left(\mathbf{k g} / \mathbf{m}^{2}\right)$ & 0.457 & $<0.001^{\mathrm{a}}$ \\
\hline WC $(\mathbf{c m})$ & 0.439 & $<0.001^{\mathrm{a}}$ \\
\hline HC $(\mathbf{c m})$ & 0.444 & $<0.001^{\mathrm{a}}$ \\
\hline WHR & 0.176 & 0.079 \\
\hline WHtR & 0.433 & $<0.001^{\mathrm{a}}$ \\
\hline LAP & 0.588 & $<0.001^{\mathrm{a}}$ \\
\hline BAI & 0.419 & $<0.001^{\mathrm{a}}$ \\
\hline BRI & 0.433 & $<0.001^{\mathrm{a}}$ \\
\hline VAI & 0.572 & $<0.001^{\mathrm{a}}$ \\
\hline AVI & 0.448 & $<0.001^{\mathrm{a}}$ \\
\hline ABSI & 0.009 & 0.929 \\
\hline
\end{tabular}

CIMT: Carotid intima-media thickness, BMI: Body Mass Index, WC: Waist circumference, HC: Hip circumference, WHR: Waist-hip ratio, WHtR: Waist-height ratio, LAP: lipid accumulation product, BAI: Body adiposity index, BRI: Body roundness index, VAI: Visceral adiposity index, AVI: Abdominal volume index, ABSI: A body shape index ${ }^{a}<0.05$ is statistically significant. 


\section{DISCUSSION}

Central obesity and dyslipidemia contribute to increased risk of atherosclerosis in women with PCOS is thought (16). Many cytokines, acute phase reactants and inflammatory mediators are released from adipose tissue and these molecules become effective on autocrine, paracrine, glucose metabolism through systematic effects, proinflammatory and inflammatory activities. Subclinical inflammation is one of the significant pathologies in patients with PCOS (17). In previous studies, it has been revealed that subclinical inflammation plays a role in atherosclerosis pathogenesis (18). CIMT is recently used as a non-invasive indicator in atherosclerosis development and many researchers have reported that increased CIMT was associated with inflammation markers and a strong indicator of stroke, myocardial infarction and cardiovascular death risk (19). Altın et al. reported that both epicardial fat thickness and CIMT was significiantly lower after laparoscopic sleeve gastrectomy in obese patients (20). In another study, it was also reported that epicardial fat thickness and CIMT was higher in patients with gestational hypertension (21). In our study, the mean value of CIMT measurements is significantly higher in the patients with PCOS. There were correlations between CIMT and LAP, BAI, BRI, VAI and AVI. These correlation shows that new anthropometric measurements might be used to predict the cardiovascular risk in patients with PCOS.

Atherosclerosis development at an early age is frequently seen in women with PCOS according to central obesity and insulin resistance. The presence of insulin resistance is the strongest factor for atherosclerosis in obese and non-obese patients with PCOS (22). The strong relationships between insulin resistance and visceral adiposity were shown in several studies $(23,24)$. It has been proved that the increased body fat might be a factor for frequently seen hyperinsulinemia, insulin resistance and dyslipidemia (25). Similarly, we found a significantly increased HOMA-IR in PCOS groups in our study. We also found positive correlations between waist circumference, waist/hip ratio, LAP, VAI, BAI, AVI, $\mathrm{BRI}$ and insulin resistance in PCOS. Increased visceral adipose tissue was related with increased insulin resistance in these patients in our study. Consequently, it is thought that body fat distribution in PCOS is an important determinant of insulin resistance. According to these results, we thought that treatments aiming to decrease visceral adipose tissue in patients might contribute to insulin sensitivity.

While obesity is known as a strong cardiovascular risk factor, it is both closely associated with general obesity and regional body fat distribution (26). Although body mass index shows general obesity, it remains incapable of de- termining body fat distribution. Besides, it has been confirmed that the increased amount of visceral fat and waist circumference were strong and independent determinants of metabolic changes (27). Therefore, new anthropometric measurements such as AVI, BAI, BRI, and VAI have been developed depending on waist circumference measurement. In our study, we have detected that visceral adipose tissue increased in patients with PCOS according to indicators as waist circumference, waist/height ratio, BRI, AVI, VAI, BAI and LAP. These values showed that the risk of abdominal obesity was higher in patients with PCOS. We also examined the anthropometric measurements' capability of predicting PCOS patients by using the ROC analysis. ROC analysis gives information about the valuable variables in prediction of PCOS. According to ROC analysis, all anthropometric parameters have the capability of predicting the risk of PCOS, except for WHR and ABSI. It is important in our study to show the best new anthropometric measurement in prediction of PCOS.

VAI is an index calculated with lipid parameters, and it is a significant indicator for visceral adipose tissue and insulin resistance (5). Recently, it has been shown that VAI is one of the best indicators of adipose tissue dysfunction, abnormal adipose distribution and insulin resistance. Besides, it has been previously reported that VAI is associated with cardio metabolic risk and subclinical inflammation (12). Previously studies showed that AVI was also a predictor for insulin resistance in diabetes and metabolic syndrome $(6,7)$. LAP is a new index to predict the deposition of central lipid tissue and is used in detection of metabolic syndrome. In recently studies, it was shown that LAP was better than BMI in predicting insulin resistance and cardiovascular risk $(8,9)$. In our study, AVI, VAI and LAP were found significantly increased in patients with PCOS. These measurements were also correlated with both CIMT and HOMA-IR. We thought that these anthropometric measurements especially VAI and LAP are good indicators for cardiovascular risk and insulin resistance.

Feng et al. have revealed that 2 new anthropometric index as BAI and BRI were useful in detecting insulin resistance in non-diabetic patients. However, neither BAI nor BRI predominates over traditional indicators such as BMI, waist circumference and AVI. It is stated that BRI is a more reasonable alternative anthropometric measurement in detecting insulin resistance, whereas BAI has weaker predictive capability (6). Similarly, Liu et al. observed that BAI was not better than BMI or waist circumference in predicting cardiovascular risk or metabolic syndrome (28). On the contrary, in other studies, BAI was found to be better than $\mathrm{BMI}$ in predicting adiposity in adults and it was implied that 
it is the best predictor for insulin resistance (29). On the other hand, Li et al. showed that BRI was better than waist circumference in predicting insulin resistance in obese and overweight people (30). Similarly, it was also shown that BRI was better in indicating body adipose distribution in comparison with waist circumference and BMI, but it did not predominate in predicting the cardiovascular risk (31). We found that CIMT was positively correlated with BAI and BRI in our study. There was also correlation between insulin resistance and BAI and BRI in our study. These results show us that BAI and BRI are both good indicator in detection of cardiovascular risk and insulin resistance in PCOS.

The limited number of patients in groups and the absence of the follow-up period are the primary limitations of this study. The limited number of patients is not appropriate to use multiple regression analysis with significant results to show better predictor for PCOS. It might give more information about the relationship between CIMT and new anthropometric parameters and the development of cardiometabolic events in PCOS with a wide number of patients.

In conclusion, consequently all new anthropometric parameters except ABSI indicate the risk of PCOS. These parameters have a correlation with CIMT and insulin resistance with PCOS. Therefore, it is thought that the use of central obesity measurements including waist circumference will be helpful in evaluating the risk of cardiovascular morbidity and insulin resistance in PCOS. We thought that future studies are needed to enlighten which anthropometric parameter predicts the risk of PCOS best.

Acknowledgements

None

Author Contributions

Study concept/Design: Gülsüm Gönülalan, Data Collection: Gülsüm Gönülalan, Fatih Saçkan, Data Analysis and Interpretation: Gülsüm Gönülalan, Fatih Saçkan, Post draft: Güslüm Gönülalan, Critical review of the content: Gülsüm Gönülalan, Final approval and responsibility: Gülsüm Gönülalan, Supervision: Gülsüm Gönülalan, Fatih Saçkan

Conflict of Interests

The authors declare no conflicts of interest.

Funding Disclosure

This study has no sponsoring foundation and institution.

\section{Ethical Approval}

This study has been approved by The Clinical Researches Ethical Committee of Necmettin Erbakan University (Number: 2019/1915). Declaration of Helsinki was followed in this study design and report.
Peer Review Process

Extremely peer-reviewed.

\section{REFERENCES}

1. Salehi M, Bravo-Vera R, Sheikh A, Gouller A, Poretsky L. Obesity in polycystic ovary syndrome: Two disease or one? Turk JEM. 2003;4:149-157.

2. Legro RS. Polycystic ovary syndrome and cardiovascular disease: A premature association? Endocr Rev. 2003;24:302312.

3. Lemieux S, Prud'homme D, Nadeau A, Tremblay A, Bouchard C, Despres JP. Seven-year changes in body fat and visceral adipose tissue in women. Association with indexes of plasma glucose-insulin homeostasis. Diabetes Care. 1996;19:983-991.

4. Dos Santos RE, Aldrighi JM, Lanz JR, Ferezin PC, Marone MMS. Relationship of body fat distribution by waist circumference, dual- energy X-ray absorptiometry and ultrasonography to insulin resistance by homeostasis model assessment and lipid profile in obese and nonobese postmenopausal women. Gynecol Endocrinol. 2005;21:295-301.

5. Uruska A, Zozulinska-Ziolkiewicz D, Niedzwiecki P, Pietrzak M, Wierusz-Wysocka B. TG/HDL-C ratio and visceral adiposity index may be useful in assessment of insulin resistance in adults with type I diabetes in clinical practice. J Clin Lipidol. 2018;12:734-740.

6. Feng J, He S, Chen X. Body adiposity indexand body roundness index in identifying insulin resistance among adults without diabetes. Am J Med Sci. 2019;357:116-123.

7. Chen S, Chen Y, Liu X, Li M, Wu B, Li Y, Liang Y, Shao X, Holthöfer $\mathrm{H}, \mathrm{Zou} \mathrm{H}$. Insulin resistance and metabolic syndrome in normal-weight individuals. Endocrine. 2014;46:496-504.

8. Kahn HS. The lipid accumulation product is better than BMI for identifying diabetes: A population-based comparison. Diabetes Care. 2006;29:151-153.

9. Kahn HS. The lipid accumulation product performs better than the body mass index for recognizing cardiovascular risk: A population-based comparison. BMC Cardiovasc Disord. 2005;5:26.

10. Rotterdam ESHRE/ASRM Sponsored PCOS Consensus Workshop Group. Revised 2003 consensus on diagnostic criteria and long-term health risks related to polycystic ovary syndrome. Fertil Steril. 2004;81:19-25.

11. Tsigos C, Hainer V, Basdevant A, Finer N, Fried M, MathusVliegen E, Micic D, Maislos M, Roman G, Schutz Y, Toplak H, Zahorska-Markiewicz B, Obesity Management Task Force of the European Association for the Study of Obesity. Management of obesity in adults: European clinical practice guidelines. Obesity Facts. 2008;1:106-116.

12. Amato MC, Giordano C, Galia M, Criscimanna A, Vitabile S, Midiri M, Galluzzo A, AlkaMeSy Study Group. Visceral Adiposity Index: a reliable indicator of visceral fat function associated with cardiometabolic risk. Diabetes Care. 2010;33:920-922. 
13. Bergman RN, Stefanovski D, Buchanan TA, Sumner AE, Reynolds JC, Sebring NG, Xiang AH, Watanabe RM. A better index of body adiposity. Obesity (Silver Spring). 2011;19:10831089.

14. Thomas DM, Bredlau C, Bosy-Westphal A, Mueller M, Shen W, Gallagher D, Maeda Y, McDougall A, Peterson CM, Ravussin E, Heymsfield SB. Relationships between body roundness with body fat and visceral adipose tissue emerging from a new geometrical model. Obesity (Silver Spring). 2013;21:2264-2271.

15. Arslan M, Atmaca A, Ayvaz G, et al. (Türkiye Endokrinoloji ve Metabolizma Derneği Metabolik Sendrom Çalışma Grubu). Metabolik Sendrom Klavuzu 2009. (Accessed at http:// http:// temd.org.tr/admin/uploads/tbl_yayinlar/metabolik_sendrom. pdf)

16. Goldzieher J, Green J. The polycystic ovary. I. Clinical and histologic features. J Clin Endocrinol Metab. 1962;22:325-338.

17. Spritzer PM, Lecke SB, Satler F, Morsch DM. Adipose tissue dysfunction, adipokines, and low-grade chronic inflammation in polycystic ovary syndrome. Reproduction. 2015;149: 219227.

18. Jain S, Khera R, Corrales-Medina VF, Townsend RR, Chirinos JA. Inflammation and arterial stiffness in humans. Atherosclerosis. 2014;237:381-390.

19. Peters SAE, Grobbee DE, Bots ML. Carotid intima-media thickness: A suitable alternative for cardiovascular risk as outcome? Eur J Cardio Prevention and Rehab. 2011;18:167174.

20. Altin C, Erol V, Aydin E, Yilmaz M, Tekindal M.A, Sade LE, Gülay H, Müderrisoğlu H. Impact of weight loss on epicardial fat and carotid intima media thickness after laparoscopic sleeve gastrectomy: A prospective study. Nutr Metab Cardiovasc Dis. 2018;28:501-509.

21. Altin C, Yilmaz M, Ozsoy HM, Gezmis E, Balci S, Tekindal MA, Sade LE, Muderrisoglu H. Assessment of epicardial fat and carotid intima media thickness in gestational hypertension. J Obstet Gynaecol Res. 2018;44:1072-1079.

22. Bozkırlı E, Bakıner O, Ertörer E, Anafaroğlu İ, Tütüncü NB, Demirağ NG. Insulin resistance in non-obese polycystic ovary syndrome subjects and relation with family history of diabetes mellitus. Turk JEM. 2015;19:55-59.
23. Anan F, Masaki T, Umeno Y, Iwao T, Yonemochi H, Eshima $\mathrm{N}$, Saikawa T, Yoshimatsu H. Correlations of visceral fat accumulation and atherosclerosis in Japanese patients with type 2 diabetes mellitus. Metabolism. 2008;57:280-284.

24. Gastaldelli A, Miyazaki Y, Pettiti M, Matsuda M, Mahankali S, Santini E, DeFronzo RA, Ferrannini E. Metabolic effects of visceral fat accumulation in type 2 diabetes. J Clin Endocrinol Metab. 2002;87:5098-5103.

25. Shen S, Lu Y, Dang Y, Qi H, Shen Z, Wu L, Li F, Yang C, Qiang D, Yang Y, Shui K, Bao Y. Effect of aerobic exercise on the atherogenic index of plasma in middle-aged Chinese men with various body weights. Int J Cardiol. 2017;230:1-5.

26. Elffers TW, de Mutsert R, Lamb HJ, de Roos A, Willems van Dijk K, Rosendaal FR, Jukema JW, Trompet S. Body fat distribution, in particular visceral fat, is associated with cardiometabolic risk factors in obese women. PLoS One. 2017;12:e0185403

27. Barbalho SM, Oshiiwa M, Sato Fontana LC, Ribeiro Finalli EF, Paiva Filho ME, Machado Spada AP. Metabolic syndrome and atherogenic indices in school children: A worrying panorama in Brazil. Diabetes Metab Syndr. 2017;11:397-401.

28. Liu PJ, Ma F, Lou HP, Zhu YN. Body roundness index and body adiposity index: Two new anthropometric indices to identify metabolic syndrome among Chinese postmenopausal women. Climacteric. 2016;19:433-439.

29. Johnson W, Chumlea WC, Czerwinski SA, Demerath EW. Concordance of the recently published body adiposity index with measured body fat percent in European-American adults. Obesity (Silver Spring). 2012;20:900-903.

30. Li G, Wu HK, Wu XW, Cao Z, Tu YC, Ma Y, Li BN, Peng QY, Cheng J, Wu B, Zhou Z. The feasibility of two anthropometric indices to identify metabolic syndrome, insulin resistance and inflammatory factors in obese and overweight adults. Nutrition. 2019;57:194-201.

31. Maessen MF, Eijsvogels TM, Verheggen RJ, Hopman MTE, Verbeek ALM, de Vegt F. Entering a new era of body indices: the feasibility of a body shape index and body roundness index to identify cardiovascular health status. PLoS One. 2014;9:e107212. 